\title{
In vivo and in vitro studies on the viability and the infectivity to coots, Fulica americana, of Cyclocoelum mutabile metacercariae from three species of snails
}

\author{
Christopher W. MCKindsey, Jonas K. Goring, and J. Daniel MCLaughlin' \\ Department of Biology, Concordia University, 1455 de Maisonneuve Boulevard West, Montréal, QC H3G 1M8, Canada
}

Received January 4, 1994

Accepted March 30, 1994

\begin{abstract}
MCKindsey, C.W., Goring, J.K., and MCLaughlin, J.D. 1994. In vivo and in vitro studies on the viability and the infectivity to coots, Fulica americana, of Cyclocoelum mutabile metacercariae from three species of snails. Can. J. Zool. 72: 1186-1190.

The host response to and the viability and infectivity of metacercariae of Cyclocoelum mutabile were examined in three species of pulmonate snails, Stagnicola elodes, Gyraulus parvus, and Promenetus exacuous. Host response was generally similar among snail species at 8 weeks post infection. Host responses increased with age of infection in $S$. elodes. There was no difference in the excystment success of metacercariae from each species at 8 weeks post infection. The mean excystment time in vitro was greater for metacercariae from $S$. elodes than for those from either $G$. parvus or $P$. exacuous at 8 weeks post infection. There were no differences in either excystment success or mean excystment time of metacercariae from 5-, 8 -, and 30-week-old infections from $S$. elodes. The mean infection success of metacercariae from $S$. elodes was lower than that of metacercariae from $G$. parvus and P. exacuous in juvenile coots. Adult coots were less susceptible to infection than juveniles. There was no difference in the infection levels established in naive and previously infected adult coots.
\end{abstract}

MCKindsey, C.W., Goring, J.K., et MCLaughlin, J.D. 1994. In vivo and in vitro studies on the viability and the infectivity to coots, Fulica americana, of Cyclocoelum mutabile metacercariae from three species of snails. Can. J. Zool. 72 : $1186-1190$.

La réaction des hôtès de même que la viabilité et le caractère infectieux des métacercaires de Cyclocoelum mutabli ont été examinés chez trois espèces de gastropodes pulmonés, Stagnicola elodes, Gyraulus parvus et Promenetus exacuous. La réaction était généralement semblables chez toutes les espèces d'hôtes 8 semaines après l'infection et elle augmentait en fonction de la durée de l'infection chez $S$. elodes. Huit semaines après l'infection, les métacercaires provenant des trois espèces avaient les mêmes chances de succès à l'enkystement chez les foulques. La durée moyenne de l'enkystement in vitro après 8 semaines était plus longue chez les métacercaires provenant de $S$. elodes que chez les métacercaires provenant de $G$. parvus ou de $P$. exacuous. Le succès de l'enkystement et la durée moyenne de l'enkystement des métacercaires provenant de $S$. elodes étaient les mêmes après 5,8 et 30 semaines d'infection. Les métacercaires de $S$. elodes avaient un succès moyen d'infection chez les foulques plus faible que les métacercaires provenant de $G$. parvus ou de $P$. exacuous. Les foulques adultes étaient moins susceptibles de devenir infectées que les jeunes. La gravité des infections était la même chez les foulques adultes qui n'avaient jamais été infectées et chez celles qui avaient déjà été victimes d'infections.

[Traduit par la Rédaction]

\section{Introduction}

Members of the digenean family Cyclocoelidae infect the respiratory systems of birds. The miracidia display a low level of host specificity and several families of snails may serve as intermediate hosts (e.g., Scott et al. 1982; Taft 1972, 1974, 1975, 1986; Taft and Heard 1978; Timon-David 1955). Development in molluscs is confined to a single redial generation and the cercariae encyst as metacercariae within the same snail.

Previous studies demonstrated that the response to infection by the cyclocoelid Typhlocoelum cucumerinum varied among snail species and that the metacercariae from different snail species varied widely in their infectivity to ducklings (Scott et al. 1982). Thus, while cyclocoelids can infect a range of snail species, the metacercariae may not be equally infective to the definitive host.

Cyclocoelum mutabile infects the air sacs of coots (Fulica spp.), and several species of snails may serve as intermediate hosts (McDonald 1969; McLaughlin 1976; McKindsey 1993). Adult coots arrive on the Canadian prairies with patent infections each spring (Colbo 1965; McLaughlin 1986). At this time, there is virtually no recruitment of new infections,

'Author to whom all correspondence should be addressed. apparently as a result of over-winter extinction of infections in the snail community (McKindsey 1993). Most infections disappear in adult coots by mid-June (Colbo 1965; McLaughlin 1986). Recruitment of new infections, mostly by juvenile coots, begins in mid-July and continues until fall migration, at which time nearly $80 \%$ of the juvenile cohort may be infected (McLaughlin 1986).

Maximum survival of $C$. mutabile in the coot host is between 16 and 20 weeks (McLaughlin 1986). Thus, infections acquired during late summer do not survive the winter, so flukes present in adults arriving on the prairies in spring represent populations acquired during the winter.

Parasite transmission depends upon the availability of susceptible hosts. The implication for $C$. mutabile is that suitable snail hosts are available in the wintering areas as well as on the prairies and that older and (or) previously infected coots are susceptible to infection during the winter.

As differential responses to cyclocoelid infection occur in at least one snail-fluke system that apparently affect the viability of the metacercariae (Scott et al. 1982), it is possible that the structure of snail communities in individual wetlands may influence transmission of cyclocoelids. Further, age and (or) acquired resistance may influence the infections that develop in coots during the winter and ultimately may affect 
development of infective pools in snails on the breeding grounds later in the spring. Either or both of these factors could affect the annual transmission of cyclocoelids.

This study is divided into two parts. The first part examines the host response of three species of snails to infection by C. mutabile, evaluates the success and timing of excystment of metacercariae from each species in vitro, and compares the infection success of metacercariae from each species in juvenile coots. The second part compares the infection success of metacercariae in naive juvenile, adult, and previously exposed adult coots to determine whether age or previous exposure influences the proportion of coots that become infected or the size of the fluke populations that develop.

\section{Materials and methods}

The flukes were originally collected from wild coots. Laboratory infections were established in $S$. elodes and the metacercariae were used to infect laboratory-reared coots. Details regarding the collection, raising, and infection of coots can be found in McLaughlin (1977). Laboratory-raised S. elodes (Lymnaeidae) and wild-caught $G$. parvus and $P$. exacuous (Planorbidae) were used in the experimental studies. Wild-caught snails were held in the laboratory for a minimum of 1 week prior to use and each was examined with a dissecting microscope for digenean infection before being exposed. No infections of $C$. mutabile were observed and snails harbouring other digeneans were not used. None of the snails used had extraneous infections when dissected later. These species were selected because of their high relative abundance in ponds studied in the Delta Marsh and because of their susceptibility to infection (McKindsey 1993). Snail species were kept in separate plastic aquaria $(38 \times 25 \times 14 \mathrm{~cm})$ at low densities $(<100$ per aquarium) and maintained on a diet of romaine lettuce (raw for S. elodes, boiled for the others) and Nutra Fin Staple Food Tablets (Rohlf C. Hagan Inc., Montréal, Quebec). Aquarium water was partially changed twice a week. Powdered chalk was provided as a source of calcium carbonate.

Miracidia were obtained from eggs removed from the uteri of gravid worms obtained at necropsy of coots. Single snails $(2-4 \mathrm{~mm}$ in length or diameter, depending on the species) were exposed to two or three miracidia in wells of 24-well tissue culture plates for $12 \mathrm{~h}$ and then transferred to aquaria.

Thirty snails ( 10 of each species) infected for 8 weeks and 10 S. elodes infected for 30 weeks were used for histological studies. Snails were relaxed overnight in about $100 \mathrm{~mL}$ of culture water to which a few crystals of menthol had been added, fixed in $5 \%$ buffered formalin $(72 \mathrm{~h})$, and then stored in $70 \%$ ethanol. The snails were decalcified in a $1 \%$ solution of $\mathrm{HCl}$ in $70 \%$ ethanol for $24 \mathrm{~h}$, dehydrated, cleared in xylene, and embedded in paraffin. The snails were serially sectioned at $10 \mu \mathrm{m}$ and stained with Ehrlich's haematoxylin and eosin. Sections were examined microscopically and scored qualitatively for haemocyte response. Four arbitrary categories were established: no visible response, a thin non-continuous layer of haemocytes associated with the metacercariae, a continuous layer of haemocytes surrounding the metacercariae, and complete encapsulation in muscular tissue. Each snail was considered a replicate and was classified in the category corresponding to the extreme level of response noted in that individual.

To examine viability, metacercariae from 10 snails of each species infected for 8 weeks and metacercariae from two groups of $10 \mathrm{~S}$. elodes infected for 5 and 30 weeks were excysted in vitro. Snails were crushed between two petri dishes and the metacercariae were dissected from the tissue. Metacercariae from all snails were recovered within $15 \mathrm{~min}$ by three people dissecting arbitrarily chosen snails, thus minimizing any potential treatment effects.

Metacercariae from each snail were placed in separate petri dishes with enough Tyrode's solution at $40^{\circ} \mathrm{C}$ to cover them. As preliminary trials revealed that pretreatment with acid-pepsin did not enhance the success or rate of excystment, this step was not included. Dishes were filled with a freshly mixed solution of $0.5 \%$ coot bile and $0.5 \%$ trypsin (Anachemia 1:100) by mass in Tyrode's solution at $40^{\circ} \mathrm{C}$ (McLaughlin and McGurk 1982) and placed in a water bath at $40^{\circ} \mathrm{C}$. All metacercariae were treated at the same time with the same stock solution. Each dish was examined after $60 \mathrm{~min}$ and at 30 -min intervals thereafter for $390 \mathrm{~min}$. The number of metacercariae that excysted during each interval was recorded and the population of metacercariae from each snail was considered a replicate.

Infectivity of metacercariae from the different snail species was tested in vivo in laboratory-raised coots. Thirty juveniles ( 2 months old) were randomly divided into three equal groups and each bird in each group was given 25 metacercariae from $S$. elodes, $P$. exacuous, or $G$. parvus. In addition, 8 naive and 10 adult coots infected 20 weeks previously (infections were confirmed by faecal examination) each received 25 metacercariae from $G$. parvus. Previously exposed coots received an initial dose of 25 metacercariae each. As $C$. mutabile survives less than 20 weeks in coots (McLaughlin 1986), coots should have been free of the previous infection when challenged. All metacercariae used were from 7-to 8-week-old infections.

For each group of hosts, sufficient snails from each species were dissected to obtain the required metacercariae. These were pooled, subdivided into doses, and administered by oral intubation. Juvenile and adult coots were exposed to metacercariae from $G$. parvus on the same day; juveniles receiving metacercariae from $S$. elodes and $P$. exacuous were exposed on the subsequent 2 days. Coots were necropsied at 4-5 weeks post infection (p.i.) to determine the number of flukes that established in each bird.

\section{Results}

The responses observed in the different groups of snails are summarized in Table 1. At 8 weeks p.i., most of the snails exhibited either no response or only a slight response to the infection. Two S. elodes and one P. exacuous had metacercariae that were completely surrounded by haemocytes and one S. elodes had metacercariae in the musculature. The response in $S$. elodes was more pronounced at 30 weeks p.i., and most individuals had encapsulated metacercariae embedded in the musculature of the head foot.

The mean excystment success (\%) of metacercariae from 8 -week-old infections did not differ significantly among the three species (ANOVA, $F=1.96, P=0.160$ ) (Table 2). There were no significant differences in the mean excystment success of metacercariae from $S$. elodes infected for 5, 8, and 30 weeks (ANOVA, $F=3.15, P=0.059$ ) (Table 2).

The mean excystment time for metacercariae from 8 -week-old infections in $S$. elodes was greater than that observed in either $P$. exacuous or G. parvus (Kruskal-Wallis test corrected for ties, $H=51.89, P<0.0005$ ) (Table 3). There was no difference in the mean excystment times of metacercariae from the latter two species. The percentage of metacercariae that excysted at each interval is shown in Fig. 1. The majority of metacercariae from P. exacuous and G. parvus excysted within the first $60 \mathrm{~min}$, whereas less than half of those from $S$. elodes did so. The mean excystment times for metacercariae from 5-, 8-, and 30-week-old S. elodes infections were similar (Kruskal-Wallis test corrected for ties, $H=4.961$, $P=0.084)$.

The proportions of metacercariae from different snail species that successfully infected coots are given in Table 4 . Based on the results of the excystment studies, we may propose a priori that the metacercariae from $S$. elodes may be less infective to coots than those from either P. exacuous or $G$. parvus. Accordingly, two tests with a single degree of freedom were done, along with the overall ANOVA (Sokal and Rohlf 1981). There were no significant differences among 
TABLE 1. Qualitative comparison of the haemocyte response in three species of snails infected with Cyclocoelum mutabile

\begin{tabular}{lccccc}
\hline & \multirow{2}{*}{$\begin{array}{c}\text { Age of } \\
\text { infection } \\
\text { Snail species }\end{array}$} & \multicolumn{4}{c}{ Type of response* } \\
\cline { 3 - 6 } & (weeks) & 0 & + & ++ & +++ \\
\hline Stagnicola elodes & 8 & 2 & 5 & 2 & 1 \\
Promenetus exacuous & 30 & 0 & 2 & 1 & 7 \\
Gyraulus parvus & 8 & 3 & 6 & 1 & 0 \\
& 8 & 4 & 6 & 0 & 0 \\
\hline
\end{tabular}

$* 0$, no detectable response; + , noncontinuous layer of haemocytes; ++ continuous layer of haemocytes; +++, encapsulated in musculature.

TABLE 2. Comparison of the percentages of Cyclocoelum mutabile metacercariae excysting in vitro from snails of three different species and ages

\begin{tabular}{lccc}
\hline \hline & $\begin{array}{l}\text { Age of } \\
\text { infection } \\
\text { (weeks) }\end{array}$ & \multicolumn{2}{c}{ Percent excysted } \\
\cline { 3 - 4 } Snail species & 5 & Mean & SE \\
\hline Stagnicola elodes & 8 & 39 & 5.5 \\
& 30 & 65 & 7.8 \\
Promenetus exacuous & 8 & 72 & 7.8 \\
Gyraulus parvus & 8 & 60 & 4.0 \\
\end{tabular}

the numbers of metacercariae from the different species that established in juvenile coots (ANOVA, $F=3.145, P=0.059$ ). However, the tests with a single degree of freedom showed that while the infection success of metacercariae from $P$. exacuous and $G$. parvus did not differ $(F=1.646, P=0.210)$, metacercariae from $S$. elodes were less infective to juvenile coots $(F=4.644, P=0.040)$.

All of the juvenile coots exposed to metacercariae from $G$. parvus became infected. However, only 3 of the 10 previously infected adult coots and only 2 of the 8 naive adult coots became infected. A significantly higher percentage of the G. parvus metacercariae established as flukes in juvenile coots $(43.6 \%$ of the initial dose) than in adult coots $(2.0 \%)$ (Mann-Whitney $U$ test, $Z=3.780, P=0.0002$ ).

Prior exposure to $C$. mutabile did not influence the susceptibility of adult coots to infection by the parasite (Fisher's exact test, $P=1.00$ ). There was also no significant difference in the percentages of flukes parasitizing previously infected or naive adults coots (Mann-Whitney $U$ test, $Z=1.066, P=$ 0.286 ).

\section{Discussion}

Responses to $C$. mutabile infections varied among and within snail species. Variability in response among species was expected, based on earlier work on the related Typhlocoelum cucumerinum by Scott et al. (1982). Variation in response within species has been reported in other snail-fluke systems (e.g., Biomphalaria glabrata Echinostoma lindoense) by Lie et al. (1987). Responses at 4 weeks p.i. were generally light in all three species. Scott et al. (1982) reported a similar light response in Helisoma trivolvis infected with $T$. cucumerinum for comparable periods but, in contrast to our study, found no response in either S. elodes or Physa gyrina. The response in $S$. elodes in this study was more intense in the case of older infections, with metacercariae

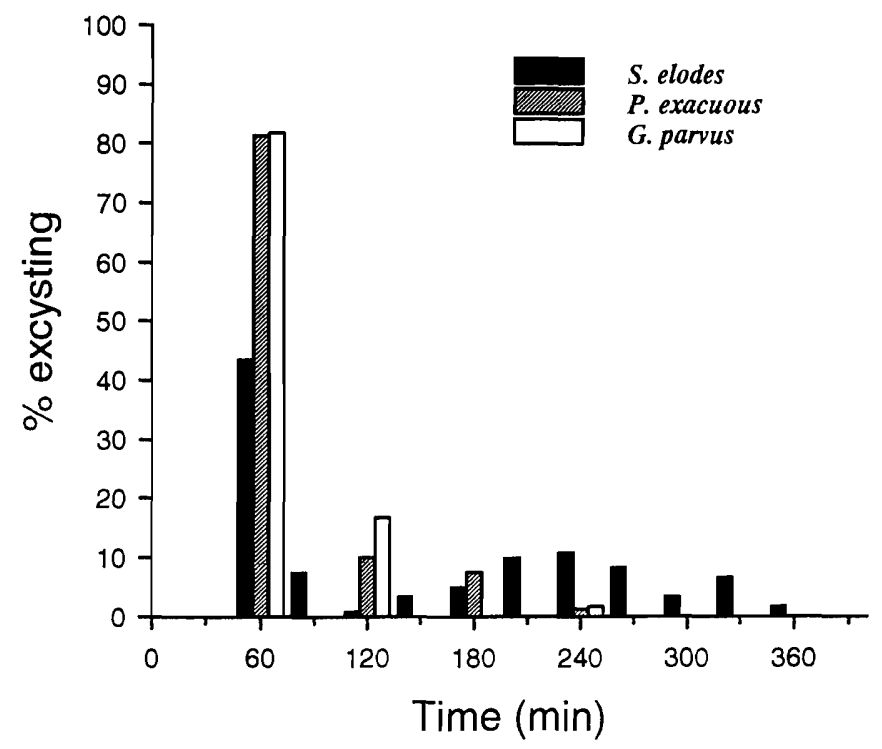

FIG. 1. Percent excystment times of Cyclocoelum mutabile metacercariae from three species of snails in $0.5 \%$ coot bile and $0.5 \%$ trypsin in Tyrode's solution at $40^{\circ} \mathrm{C}$.

TABLE 3. Mean excystment times of Cyclocoelum mutabile metacercariae in vitro from three species of snails and from infections of different ages

\begin{tabular}{lcccc}
\hline \hline & & $\begin{array}{c}\text { Age of } \\
\text { Snail species }\end{array}$ & $n$ & $\begin{array}{c}\text { Excystment } \\
\text { time (min) }\end{array}$ \\
\cline { 4 - 5 } Stagnicola elodes & 42 & 5 & 157.1 & 11.2 \\
& 122 & 8 & 153.2 & $9.0 a$ \\
Promenetus exacuous & 121 & 30 & 131.2 & 8.2 \\
Gyraulus parvus & 80 & 8 & 77.3 & $4.4 b$ \\
\hline
\end{tabular}

NOTE: Values followed by a different letter are significantly different (Dunn's test, $P<0.001$ ).

TABLE 4. Infectivity to juvenile and adult coots of $C y$ clocoelum mutabile metacercariae from 7- to 8-week-old infections in three species of snails

\begin{tabular}{llcr}
\hline & & \multicolumn{2}{c}{ Infection success (\%) } \\
\cline { 4 - 5 } $\begin{array}{l}\text { Source of } \\
\text { metacercariae }\end{array}$ & Coot age & Mean & SE \\
\hline Gyraulus parvus & Juvenile & 43.6 & 4.9 \\
Stagnicola elodes & Juvenile & 26.4 & 3.7 \\
Promenetus exacuous & Juvenile & 35.2 & 5.7 \\
Gyraulus parvus & Adult (n) & 2.0 & 1.1 \\
Gyraulus parvus & Adult (p) & 4.5 & 1.9 \\
\hline
\end{tabular}

NoTE: $\mathrm{n}$, naive; $\mathrm{p}$, previously exposed to and infected by $C$. mutabile.

becoming encapsulated or completely sequestered in muscle. Encapsulation is part of the normal defence process in snails (van der Knaap and Loker 1990) and it has also been reported by Scott et al. (1982) to occur in H. trivolvis infected with T. cucumerinum.

Although similar proportions of metacercariae from 8-week-old infections excysted in vitro, species-related differences in excystment times were evident. Metacercariae from $S$. elodes required, on average, about twice as long to excyst as those from P. exacuous or G. parvus. This delay, 
coupled with the high passage rate of food in the avian gut (Duke 1986), could account for the lower numbers of flukes found in coots exposed to metacercariae from $S$. elodes and may also explain the low proportion of flukes $(10-21 \%)$ recovered by McLaughlin (1986) in a similar study using metacercariae from this species. A large proportion of the metacercariae may excyst in suboptimal regions of the gut and fail to establish, or perhaps be passed before excystment occurs.

Although species-related differences in excystment times occurred, our data on the host responses provides little insight into the factors that might cause them. The histological responses in all species of snails at 8 weeks were visually similar. However, we did observe that metacercariae dissected from $S$. elodes were sticky and adhered to tissue, instruments, and glassware to a much greater extent than those from the other species, possibly reflecting a greater or a different host response. A more effective host response in $S$. elodes could affect the infectivity of the metacercariae by weakening them directly. Alternatively, a stronger host response may limit the diffusion of chemicals normally involved in the activation and excystment of the metacercariae. Scott et al. (1982) found that although there was no apparent response to metacercariae of $T$. c. sisowi in S. elodes at 2 months p.i., they failed to produce infections when fed to mallards (Anas platyrhynchos), which suggests that factors other than haemocyte response may also influence infectivity.

We acknowledge that the different snail species used were not necessarily at the same developmental stage nor, presumably, at the same level of immunocompetence. However, a comparison of responses elicited in individuals of the same age from other species would have involved using snails of greatly differing sizes. We believe that comparing individuals of the same size from different snail species would yield more meaningful results than using snails of the same age. The internal defence system of lymnaeids is more developed in larger snails (Dikkeboom et al. 1985; van der Knaap and Meuleman 1986) and the use of larger S. elodes may have shown even greater differences than were seen in this study.

The long-term effects of snail responses to metacercariae of $C$. mutabile are unknown. Scott et al. (1982) observed that $H$. trivolvis infected with $T$. cucumerinum for longer periods exhibited an intense host response, but that this was absent in $P$. gyrina and $S$. elodes. They speculated that metacercariae subjected to this level of response in $H$. trivolvis were incapable of infecting ducks. Although the response in S. elodes in our study was greater at 30 weeks than at 8 weeks, there was no difference in the proportions of metacercariae that excysted in vitro, and it seems reasonable to suppose that some of these might have been infective.

McKindsey (1993) has shown that the transmission window for $C$. mutabile to snails in the Delta Marsh is $8-10$ weeks, extending from about the end of June to the beginning of September. Coots on the Canadian prairies acquire infections between mid-July and September (Colbo 1965; McLaughlin 1986). During this period, any response that developed in natural populations of these snails should be comparable to the 8 -week response reported here. Our data suggest that in the short term, the source of metacercariae (i.e., the snail species) has little effect on the prevalence of $C$. mutabile in coots but, in view of the differences in infectivity noted above, may influence the intensity of the infection in individual coots. However, the presumably longer relationship between snails and $C$. mutabile and the wider transmission window for this parasite to coots on the coots' wintering grounds may allow the differential host responses seen here to have a greater influence on the transmission of the parasite on the wintering grounds.

Under natural conditions, juvenile coots are more heavily infected than adults (Colbo 1965; McLaughlin 1986). This may be partially explained by differences in exposure to the parasite due to the food habits or spatial distribution of the two age-classes. Coots feed predominantly on animal matter as juveniles, but switch to a diet mostly consisting of vegetation as they age (Jones 1940; Driver 1988). Males and nonbreeders congregate on larger water bodies in late summer, while juveniles remain closer to the nesting site (Ryder 1963; P. Ward, personal communication). As rates of infection in snail populations are often highest near bird roosts and nests (Sousa and Grosholz 1991 and references therein), the juveniles would be expected to carry a heavier burden of the fluke.

Differences in infection levels may also be partially explained by differential susceptibility of individuals in the two age-classes. Although both juvenile and adult coots were successfully infected, fewer adults became infected and a lower proportion of the metacercariae fed to adults developed into flukes. These results differ from those of McLaughlin (1986), who found no differences in the proportion of coots in different age-classes that became infected following exposure to metacercariae from $S$. elodes. It is apparent that there is extensive variability in susceptibility within the adult cohort to infection with $C$. mutabile.

Prior exposure to the fluke seems to have little effect on the susceptibility of adult coots to further infection. This is consistent with earlier observations by McLaughlin (1986), who found concurrent $C$. mutabile infections to have no effect on either the proportion of juvenile coots that became infected following challenge doses or on the intensity of challenge infections that developed.

There is good empirical (McKindsey 1993) and inferred evidence (Colbo 1965; McLaughlin 1986) to suggest that $C$. mutabile does not overwinter successfully in snails on the breeding grounds. McLaughlin (1986) demonstrated that this fluke survives for less than 20 weeks in the coot. Thus, coots must acquire infections a second time on the wintering grounds in order to return with flukes the following spring. The ability of $C$. mutabile to establish in naive and previously infected adult coots is an essential feature of the ecology of this fluke.

\section{Acknowledgements}

C.W.M. thanks the many individuals who assisted during the summer fieldwork at the Delta Waterfowl and Wetlands Research Station, without whom this work could not have been completed. The Canadian Wildlife Service generously supplied the necessary permits required for the collection of coots and coot eggs. We thank Dr. Frank Rohwer and Mr. Peter Ward for making the facilities at Delta Marsh available for this study. Financial support to C.W.M. for this research was provided by the North American Wildlife Foundation through a Graduate Research Grant and through a demonstratorship from the Department of Biology, Concordia University. 
The suggestions of two anonymous reviewers are greatly appreciated.

Colbo, M.H. 1965. Taxonomy and ecology of the helminths of the American coot in Alberta. M.Sc. thesis, The University of Alberta, Edmonton.

Dikkeboom, R., van der Knaap, W.P.W., Meuleman, E.A., and Sminia, T. 1985. A comparative study on the internal defence system of juvenile and adult Lymnaea stagnalis. Immunology, 55: 547-553.

Driver, E.A. 1988. Diet and behaviour of young American coots. Wildfowl, 39: 34-42.

Duke, G.E. 1986. Alimentary canal: anatomy, regulation of feeding, and motility. In Avian physiology. Edited by P.D. Sturkie. Springer-Verlag, New York. pp. 269-285.

Jones, J.C. 1940. Food habits of the American coot with notes on distribution. Wildlife Research Bull. No. 2, U.S. Department of the Interior, Washington, D.C

Lie, K.J., Jeong, K.H., and Heyneman, D. 1987. Molluscan host reactions to helminthic infection. In Immune responses in parasite infections: immunology, imunopathology, and immunoprophylaxis. Vol. IV. Protozoa, arthropods, and invertebrates. Edited by E.J.L. Soulsby. CRC Press Inc., Boca Raton, Fla. pp. 211-270.

McDonald, M.E. 1969. Catalogue of the helminths of waterfowl (Anatidae). Spec. Sci. Rep. U.S. Fish Wildl. Serv. No. 126.

McKindsey, C.W. 1993. Lab and field studies on the establishment of Cyclocoelum mutabile (Zeder, 1800) (Digenea) infections in snail communities. M.Sc. thesis, Concordia University, Montréal.

McLaughlin, J.D. 1976. Experimental studies on the life cycle of Cyclocoelum mutabile (Zeder) (Trematoda: Cyclocoelidae). Can. J. Zool. 54: 48-54.

McLaughlin, J.D. 1977. The migratory route of Cyclocoelum mutabile (Zeder) (Trematoda: Cyclocoelidae) in the American coot, Fulica americana (Gm.). Can. J. Zool. 55: 274-279.

McLaughlin, J.D. 1986. The biology of Cyclocoelum mutabile (Trematoda) infections in American coots. Proc. Helminthol. Soc. Wash. 53: 177-181.

McLaughlin, J.D., and McGurk, B.P. 1982. The chick as an experimental host for Cyclocoelum mutabile (Zeder, 1800) (Digenea). Proc. Helminthol. Soc. Wash. 49: 327-329.
Ryder, R.A. 1963. Migration and population dynamics of American Coots in western North America. Proc. Int. Ornithol. Congr. 13: 441-453.

Scott, M.E., Rau, M.E., and McLaughlin, J.D. 1982. A comparison of aspects of the biology of two subspecies of Typhlocoelum cucumerinum (Digenea: Cyclocoelidae) in three families of snails (Physidae, Lymnaeidae and Planorbidae). Int. J. Parasitol. 12: 123-133

Sokal, R.R., and Rohlf, F.J. 1981. Biometry: the principles and practice of statistics in biological research, 2nd ed. W.H. Freeman and Co., San Francisco.

Sousa, W.P., and Grosholz, E.D. 1991. The influence of habitat structure on the transmission of parasites. In Habitat structure: the physical arrangement of objects in space. Edited by S.S. Bell, E.D. McCoy, and H.R. Mushinski. Chapman and Hall, London. pp. 300-324.

Taft, S.J. 1972. Aspects of the life history of Cyclocoelium oculeum (Trematoda: Cyclocoelidae). J. Parasitol. 58: 882-884.

Taft, S.J. 1974. Notes on the larval stages of Cyclocoelum vanelli (Trematoda: Cyclocoelidae). J. Parasitol. 60: 904.

Taft, S.J. 1975. Aspects of the life history of Cyclocoelum brasilianum Stossich, 1902 (Trematoda: Cyclocoelidae). J. Parasitol. 61: 1041-1043

Taft, S.J. 1986. Aspects of larval development and histochemistry of Ophthalmophagus singularis (Trematoda: Cyclocoelidae). J. Parasitol. 72: 136-141.

Taft, S.J., and Heard, R.W. 1978. Aspects of the larval development of Ophthalmophagus sp. (Trematoda: Cyclocoelidae). J. Parasitol. 64: 597-600.

Timon-Davd, J. 1955. Cycle évolutif d'un trématode Cyclocoelidae: Pseudhyptiasmus dollfusi Timon-David 1950 : recherches experimentales. Ann. Parasitol. Hum. Comp. 1-2: 43-61.

van der Knaap, W.P.W., and Loker, E.S. 1990. Immune mechanisms in trematode-snail interactions. Parasitol. Today, 6: 175-182.

van der Knaap, W.P.W., and Meuleman, E.A. 1986. Interaction between the immune system of lymnaeid snails and trematode parasites. Symp. Zool. Soc. Lond. No. 56. pp. 179-198. 